\title{
Local Raw Material, Fuel and Clinker Production Processing with 5 Stage Pre- Calciner Kiln and Grate Cooler in Georgia
}

\author{
Chkheidze V*
}

Georgian Technical University, Georgia

ISSN: 2637-8035

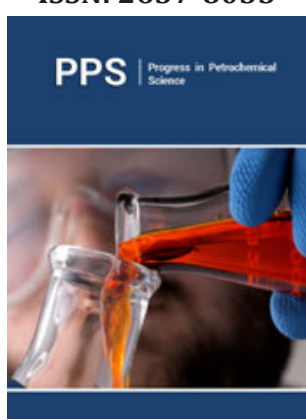

*Corresponding author: Chkheidze V, Georgian Technical University, Georgia

Submission: 闻 December 26, 2020

Published: 漈January 25, 2021

Volume 4 - Issue 1

How to cite this article: Chkheidze $\mathrm{V}$. Local Raw Material, Fuel and Clinker Production Processing with 5 Stage PreCalciner Kiln and Grate Cooler in Georgia. Progress Petrochem Sci. 4(1). PPS. 000577. 2021.

DOI: 10.31031/PPS.2021.04.000577

Copyright@ Chkheidze V, This article is distributed under the terms of the Creative Commons Attribution 4.0 International License, which permits unrestricted use and redistribution provided that the original author and source are credited.

\section{Abstract}

In Kaspi cement plant (Heidelbergcement group) the new 5 stage pre-calciner kiln (3000 TPD) was erected in 2016 and commissioned in 2018. It was a brownfield project, the existing wet plant was stopped with 3 long wet kilns, only cement grinding mills remain in operation. It is quite common thing to upgrade old process equipment with new installations but in this case source of main material, limestone was also changed, it was quite challenging.

My PHD work is related to the new production process and control concepts which were necessary to implement for keeping high production, low power and heat consumption and most importantly excellent quality to build the future.

Keywords: Clinker; Kiln; Pre-calciner; Raw materials; Production; Clinkerization; Quality; Incorporation

\section{Opinion}

Beside above-mentioned challenges with new equipment, material and fuel mix, globally, there is the most important $\mathrm{CO}_{2}$ emissions reduction challenge which is quite tough due to clinker production high heat and temperature requirement and limestone to clinker conversion nature that $\mathrm{CaCO}_{3}$ is losing $\mathrm{CO}_{2}$.

There are several scenarios how to reduce carbon dioxide footprint, like: reduction of clinker incorporation in cement, process optimization for lower heat demand for clinkerization, alternative fuels and raw materials usage for clinker production etc. In this study one of the components would be raw material utilization which is added immediately after the clinker burning process directly into the hot part of the grate cooler.

This revolutionary idea was tested in 70s by Georgian Technical University professors with very good results, like, gaining 10-20 Mpa of very early strength, in 2 hours after setting the samples. Unfortunately, it was only lab test trial and did not move any further into production.

The mentioned waste material is waste product from Aluminum production which could be a part of circular economy due to its beneficial ability to reduce carbon footprints while even increasing the clinker quality. Additionally, if clinker quality is increased it gives another room for clinker incorporation reduction in cement [1].

\section{Conclusion}

Focus of the research would be clinker production process on local raw material and fuel and clinker with 5 stage pre-calciner kiln and grate cooler in Georgia (country), process and material optimization will be additionally focused in order to reduce heat requirement while keeping or increasing the quality main parameters and having possibility to utilize the benefits in reduced clinker incorruption.

\section{References}

1. TG (2004) Ultrafast hardening waterproof Portland cement, Russia. 